\title{
Ancient rivers cut migration routes through Sahara
}

\section{Simulations suggest waters made 'green corridors' for early humans heading out of Africa.}

\section{Davide Castelvecchi}

11 September 2013

\section{Out of Africa}

Monsoons during the most recent interglacial age would have fed a number of rivers cutting through the desert, simulations suggest.

The Sahara Desert was once criss-crossed by three mighty river systems that flowed northward and could have created the conditions for the first human migrations to Europe and Asia, a study suggests.

During the period between the two most recent ice ages, some 100,000-130,000 years ago, African monsoons reached as much as 1,000 kilometres farther north than they do now and brought torrential rains to the mountain ranges south of the Sahara Desert.

Using detailed topographical data of the region, Tom Coulthard, a hydrologist at the University of Hull, UK, and his colleagues created a computer simulation of how that water would have flowed downhill towards the north, forming lakes and inland deltas and, in some cases, reaching the Mediterranean Sea. The results are published today in PLOS ONE ${ }^{1}$.

At their seasonal maximum, the major rivers would each have carried about one-quarter of the amount of water as the Nile, Coulthard says. The rivers would have created 'green corridors' of vegetation and water in the desert, enabling early modern humans to migrate north and eventually to other continents, adds Mike Rogerson, a palaeoclimatologist at the University of Hull and a co-author of the study.

Numerous settlements are known to have existed in northern Africa during the interglacial period, and Rogerson hopes that the study can help archaeologists to locate more of them.

Nature | doi:10.1038/nature.2013.13729

\section{References}


1. Coulthard, T. J., Ramirez, J. A., Barton, N., Rogerson, M. \& Brücher, T. PLoS ONE 8, e74834 (2013). 